\title{
PENDIDIKAN KARAKTER MELALUI PENINGKATAN KUALITAS LULUSAN SMA
}

\author{
Eko Rubiyanto
}

Ponpes Al Firdaus, MI Bentangan

Email: ekorubiyanto84@yahoo.co.id

\begin{abstract}
This paper aims to describe character education through improving the quality of high school graduates. This type of research is qualitative research. The research subjects are researchers and research objects of educators and students. Data collection methods through observation, tests and documentation. The data analysis technique was carried out in a descriptive qualitative manner with a flow model consisting of data collection, data reduction, data presentation, verification and conclusion drawing. The results of this study indicate that: (1) Thustworthiness character education by recognizing that the questions tested are considered difficult so that it needs to study extra hard and smart like working on HOTS questions, and strict examination supervision in accordance with existing provisions. (2) Caring character education by celebrating graduation without convoys and scribbles that violates the safety and order of others and distributes fastbreaking takjil for people who are at the intersection of lights on the highway. (3) Respect character education by respecting and respecting the achievement of academic results among students and not doing things that disturb others such as convoys that cause noise. (4) Citizenship character education by celebrating graduates by not violating school rules and not violating road traffic laws. (5) Responsibility character education by waiting for announcements in accordance with school rules, whatever academic results obtained remain grateful and continue to the next step by utilizing academic results to the fullest.
\end{abstract}

Keywords: character; thustworthiness; caring; respect; citizenship; responsibility

Abstrak. Makalah ini bertujuan untuk mendeskripsikan pendidikan karakter melalui peningkatan kualitas lulusan SMA. Jenis penelitian ini adalah penelitian kualitatif. Subyek penelitian adalah peneliti dan obyek penelitian pendidik dan peserta didik. Metode pengumpulan data melalui observasi, tes dan dokumentasi. Teknik analisis data dilakukan secara deskriptif kualitatif dengan model alur yang terdiri dari pengumpulan data, reduksi data, penyajian data, verifikasi dan penarikan kesimpulan. Hasil penelitian ini menunjukkan bahwa : (1) pendidikan karakter Thustworthiness dengan mengakui bahwa soal - soal yang diujikan dianggap sulit sehingga perlu belajar ekstra keras dan cerdas seperti mengerjakan soal HOTS, dan pengawasan ujian ketat sesuai dengan ketentuan yang ada. (2) pendidikan karakter Caring dengan perayaan kelulusan tidak konvoi dan coret-coret yang melanggar keamanan dan ketertiban orang lain dan melakukan pembagian takjil buka puasa untuk orang yang berada di perempatan lampu di jalan raya. (3) pendidikan karakter Respect dengan saling menghormati dan menghargai pencapaian hasil akademik antar peserta didik dan tidak melakukan hal-hal yang mengganggu orang lain seperti konvoi yang menimbulkan suara bising. (4) pendidikan karakter Citizenship dengan perayaan lulusan dengan tidak melanggar aturan tata tertib sekolah dan tidak melanggar aturan hukum lalu lintas di jalan raya. (5) pendidikan karakter Responsibility dengan menunggu pengumuman sesuai dengan aturan sekolah, apapun hasil akademik 
yang diperoleh tetap bersyukur dan melanjutkan ke langkah selanjutnya dengan memanfaatkan hasil akademik secara maksimal.

Kata kunci: character; thustworthiness;caring; respect; citizenship; responsibility

\section{Pendahuluan}

Pendidikan merupakan pintu masuk peserta didik untuk membahagiakan keluarga dan masyarakat dalam meraih masa depan. Proses pendidikan di Indonesia tidak luput ada partikel yang harus diperbaiki dalam meningkatkan kualitas sumber daya manusia. Berbagai usaha telah dilakukan untuk meningkatkan kualitas pendidikan, misalnya pengembangan kurikulum nasional, peningkatan kompetensi guru melalui pelatihan, penggandaan buku dan alat pelajaran, pengadaan sarana dan prasarana pendidikan, serta peningkatan manajemen sekolah. Beberapa inditator kualitas pendidikan belum menunjukkan peningkatan kualitas pendidikan yang cukup memuaskan. Pendidikan bukanlah upaya yang sederhana melainkan suatu kegiatan yang dinamis dan penuh tantangan. Setiap saat pendidikan menjadi fokus perhatian dan sasaran ketidakpuasan karena pendidikan menyangkut kepentingan setiap orang.

Institusi pendidikan merupakan tempat proses pendidikan dilakukan, memiliki sistem yang komplek dan dinamis. Pelaksanaan kegiatannya bukan hanya sekedar tempat berkumpul pendidik dengan peserta didik, tetapi dalam satu tatanan sistem yang rumit dan saling berkaitan. Oleh karena itu, institusi pendidikan dipandang suatu organisasi yang membutuhkan pengelolaan yang matang, profesional dan kemperehensif. Pengelolaan sumber daya manusia diharapkan menghasilkan lulusan bekualitas tinggi dan memiliki karakter dengan tuntutan kebutuhan masayakarat. Lulusan institusi pendidikan yang berkarakter diharapkan dapat memberikan kontribusi kepada pembangunan bangsa dan masyarakat. Institusi pendidikan diharapkan dapat meningkatkan kualitas sumber daya manusia yang berkarakter, derajat sosial, daya saing, berkualitas serta
berkarakter.Pembentukan lulusan yang berkarakter bukan suatu upaya mudah dan cepat sehingga memerlukan upaya koninuitas, kerja keras, cerdas, evaluasi dan refleksi dari berbagai elemen pendidikan.

Menurut Undang-undang No.20 tahun 2003 tentang Sistem Pendidikan Nasional pada Pasal 3, menyebutkan bahwa pendidikan nasional berfungsi mengembangkan kemampuan dan membentuk karakter serta peradaban bangsa yang bermartabat dalam rangka mencerdaskan kehidupan bangsa. Kemampuan tersebut mencakup aspek hard skill dan soft skill. Penelitian yang dilakukan di Harvard University Amerika Serikat (Muslich,2011:84) penelitian tersebut menunjukkan bahwa kesuksesan seseorang tidak ditentukan semata-mata oleh pengetahuan dan kemampuan teknis (hard skill) saja, tetapi lebih oleh kemampuan mengelola diri dan orang lain (soft skill). Penelitian tersebut mengungkapkan, kesuksesan hanya ditentukan sekitar 20 persen oleh hard skill dan sisanya 80 persen oleh soft skill.

Pencanangan pendidikan karakter dimaksudkan untuk menjadi salah satu jawaban terhadap beragam persoalan bangsa yang saat ini banyak dilihat, didengar dan dirasakan, yang mana banyak persoalan muncul yang di indentifikasi bersumber dari gagalnya pendidikan dalam mengaplikasikan nilai-nilai moral terhadap peserta didik. "Pendidikan karakter adalah keseluruhan dinamika relasional antara pribadi dengan berbagai macam dimensi, baik dari dalam maupun dari luar dirinya, agar pribadi tersebut semakin dapat menghayati kebebasan sehingga dapat bertanggung jawab atas pertumbuhan dirinya sendiri sebagai pribadi dan perkembangan orang lain dalam hidup mereka" (Doni Koesoema, 2011: 123). Permasalahan yang berhubungan dengan makin menurunnya nilai-nilai karakter siswa 
tersebut adalah sering terjadi berbagai tindak kekerasan seperti tawuran antar pelajar, mencontek, bullying, berbagai tindak asusila, perusakan fasilitas sekolah oleh siswa, meningkatnya penggunaan narkoba, dan lain sebagainya (Kesuma, 2011:41-42). Tujuan pendidikan bukan hanya melahirkan insan yang cerdas, namun juga menciptakan insan yangberkarakter kuat.

Maka dari itu, penulis memfokuskan pada peningkatan kualitas output pendidikan dan termotivasi mengangkat judul"Pendidikan karakter melalui peningkatan kualitas lulusan $S M A$ ". Secara umum tujuan dari makalah ini adalah Pendidikan karakter melalui peningkatan kualitas lulusan SMA. Sedangkan secara khusus, tujuan dari penelitian ini adalah : 1. mendeskripsikanpendidikan karakter Thustworthiness melalui peningkatan lulusan SMA, 2. mendeskripsikan pendidikan karakter Caring melalui peningkatan lulusan SMA, 3. mendeskripsikan pendidikan karakter Respect melalui peningkatan lulusan SMA, 4. mendeskripsikan pendidikan karakter Citizenship melalui peningkatan lulusan SMA, dan 5. Mendeskripsikan pendidikan karakter Responsibility melalui peningkatan lulusan SMA.

\section{Metode Penelitian}

Jenis penelitian ini merupakan penelitian kualitatif karena penelitian ini mendeskripsikan Pendidikan karakter melalui peningkatan kualitas lulusan SMA.Penelitian kualitatif adalah penelitian yang berlandaskan pada filsafat postpositivisme, digunakan untuk meneliti pada kondisi objek yang alamiah. Penelitian ini dilaksanakan di SMA Negeri 1 Wonosari Klaten di kelas XII Tahun Pelajaran 2018/2019 yang beralamatkan di Jalan Solo-Yogya, Pakis, Boto, Wonosari, Klaten. Penelitian ini dilakukan secara bertahap mulai bulan Mei 2019 sampai selesai yang meliputi tahap persiapan, tahap pelaksanaan, tahap analisis data dan tahap penyusunan laporan.

Data dalam penelitian ini berupa catatan yang disebut fieldnote. Fieldnote terdiri dari dua bagian penting, yaitu bagian deskriptif dan reflektif. Bagian deskripsi dalam fieldnote meliputi potret subjek, rekonstruksi, dialog, deskripsi keadaan fisik tentang tempat dan barang lainnya, serta catatan tentang berbagai peristiwa khusus. Bagian reflektif sebagai kelengkapan deskripsi, fieldnote berisi kalimat dan paragraf yang mencerminkan perhitungan pribadi peneliti mrngrnai berbagai hal yang diteliti. Penelitian ini bersifat kualitatif yang mengambil sumber data primer dan sekunder. Sumber data primer adalah pendidik yang melakukan tindakan dan siswa yang menerima tindakan, sedangkan data sekunder berupa data dokumentasi. Sumber data penelitian ini adalah informan, gejala, fenomena, peristiwa, proses, perilaku,aktivitas, tempat, dan dokumen. Penelitian ini menggunakan teknik snowball sampling yaitu cara pemilihan informan pada waktu di lokasi penelitian, yang kemudian berdasarkan petunjuk informan tersebut peneliti menemukan informasi baru, dan seterusnya berganti informasi lainnya yang tidak terencana sebelumnya sehingga peneliti mendapatkan data yang lengkap dan mendalam.

Pada penelitian kualitatif ini,peneliti hadir sebagi instrumen. Peneliti terlibat langsung atau tidak langsung sebagai instrumen. Peneliti menyiapkan beberapa hal yang diperlukan dalam penelitian tersebut secara lengkap supaya data yang diperoleh valid dan temuannya berkualitas. Strategi pengumpulan data penelitian kualitatif dengan metode interaktif yang meliputi wawancara mendalam dan observasi berperan dan metode non-interaktif meliputi observasi tak berperan, kuesioner, dan mencatat dokumen maupun arsip. Keabsahan dapat dilakukan melalui observasi secara terus menerus, triangulasi sumber, metode, dan peneliti lain, pengecekan anggota, diskusi teman sejawat, dan pengecekan referensi. Penelitian ini dilakukan dengan observasi dan triangulasi data. Triangulasi adalah teknik pemeriksaan keabsahan data yang memanfaatkan sesuatu yang lain di luar data untuk keperluan pengecekan sebagai pembanding terhadap data. 
Analisis data dalam penelitian ini dilakukan dengan menggunakan metode alur dimana langkah-langkah yang harus dilalui dalam metode alur meliputi pengumpulan data, penyajian data, dan verifikasi data.Proses analisis data dimulai dengan menelaah seluruh data yang tersedia dari berbagai sumber. Setelah dikaji kemudian membuat rangkuman untuk setiap pertemuan atau tindakan di kelas. Berdasarkan rangkuman yang dibuat kemudian penelitian melaksanakan reduksi data yang kegiatan mencakup unsur-unsur sebagai berikut : (a) memilih data atas dasar relevansi, (b) menyusun data dalam satuansatuan jenis, (c) memokuskan penyederhanaan dan mentransfer dari data kasar ke catatan lapangan.Pada langkah penelitian ini, peneliti berusaha menyusun data yang relevan sehingga dapat menjadi informasi yang dapat disimpulkan dan memiliki makna tertentu. Dengan cara menampilkan data dan membuat hubungan antara variabel, peneliti mengerti apa yang terjadi dan apa yang perlu ditindak lanjuti untuk mencapai tujuan penelitian. Verifikasi data atau penarikan kesimpulan dilakukan secara bertahap untuk memperoleh derajat kepercayaan tinggi. Dengan demikian, analisis data dalam penelitian dilakukan sejak tindakan dilaksanakan. Verifikasi data dilakukan pada setiap tindakan yang pada akhirnya dipadukan menjadi kesimpulan.

\section{Hasil dan Pembahasan}

Implementasi pendidikan karakter melalui peningkatan kualitas lulusan salah satunya dalam pembelajaran. Implementasi pendidikan karakter dalam pembelajaran harus dilakukan dengan strategi yang matang dengan melihat kondisi dan kemampuan siswa serta lingkungan sekitar. Menurut Wagiran (2011) menyatakan bahwa, "Pelaksanaan integrasi karakter dalam pendidikan memiliki prinsip - prinsip umum seperti: (1) tidak mengubah sistem pendidikan yang berlaku, (2) tidak mengubah kurikulum, (3) pembelajaran menggunakan prinsip learning to know, learning to learn, learning to be, dan learning to live together, dan (4) dilaksanakan secara kontekstual sehingga terjadi pertautan antara pendidikan dan kebutuhan nyata siswa". Implementasi nilai-nilai karakter pada pembelajaran untuk menanamkan nilai-nilai pada siswa akan pentingnya pendidikan karakter, sehingga mereka mampu menginternalisasikan nilai-nilai tersebut tingkah laku sehari-hari.

Kurikulum 2013 mengimplementasikan nilai-nilai pendidikan karakter di setiap mata pelajaran dengan mengintegrasikan nilai-nilai pendidikan karakter ke dalam Kompetensi Inti dan Kompetensi Dasar. Menurut Kemendiknas (2010), karakter adalah watak, tabiat, akhlak, atau kepribadian seseorang yang terbentuk dari hasil internalisasi berbagai kebajikan yang diyakini dan digunakan sebagai landasan untuk cara pandang, berpikir, bersikap, dan bertindak. Menurut Sudirman (2010) Pendidikan karakter adalah suatu sistem penanaman nilai-nilai karakter kepada warga sekolah atau kampus yang meliputi kompenen pengetahuan, kesadaran atau kemauan dan tindakan untuk melaksanakan nilai-nilai tersebut, baik terhadap Tuhan Yang Maha Esa, diri sendiri, sesama lingkungan maupun kebangsaan sehingga menjadi paripurna atau insan kamil".

Kompetensi dasar yang dapat diintegrasikan dengan nilai-nilai pendidikan karakter tersebut dikembangkan pada Rencana Program Pembelajaran (RPP). Guru berperan dalam mengintegrasikan dan mengembangkan nilai-nilai karakter ke dalam proses pembelajaran yang menyenangkan dan dapat diterima siswa sesuai dengan Kurikulum. Proses pembelajaran didasarkan pada upaya menguasai kompetensi pada tingkat yang memuaskan dengan memperhatikan karakteristik konten kompetensi dimana pengetahuan adalah konten yang bersifat tuntas. Keterampilan kognitif dan psikomotorik adalah kemampuan penguasaan konten yang dapat dilatihkan. Sedangkan sikap adalah kemampuan penguasaan konten yang lebih sulit dikembangkan dan memerlukan proses pendidikan yang tidak langsung. Guru berperan dalam membiasakan nilai- 
nilai tersebut melalui kegiatan pembelajaran merupakan point penting dalam implementasi pendidikan karakter dalam pembelajaran. Guru mengupayakannilai-nilai yang telah tertuang dalam kurikulum tersebut agar mendorong siswa untuk menjadikannya sebagai suatu pembiasaan dan tidak merasakannya sebagai sebuah beban.

Hasil temuan penelitian pendidikan karakter Thustworthiness dengan mengakui bahwa soal - soal yang diujikan dianggap sulit sehingga perlu belajar ekstra keras dan cerdas seperti mengerjakan soal HOTS, dan pengawasan ujian ketat sesuai dengan ketentuan yang ada.Menurut Imam Suyitno (2012) dalam penelitiannya menyatakan bahwa peserta didik yang memiliki karaktermulia bila memiliki pengetahuan tentang potensidirinya, yang ditandai dengan nilai-nilaiseperti reflektif, percaya diri, rasional,logis, kritis, analitis, kreatif dan inovatif,mandiri, hidup sehat, bertanggung jawab,cinta ilmu, sabar, berhati-hati, rela berkorban,pemberani, dapat dipercaya, jujur, menepatijanji, adil, rendah hati, malu berbuatsalah, pemaaf, berhati lembut, setia, bekerja keras, tekun, ulet, teliti, berinisiatif,berpikir positif, disiplin, antisipatif, inisiatif,visioner, bersahaja, bersemangat, dinamis, efisien, menghargai waktu,dedikatif, pengendalian diri,produktif, ramah, cinta keindahan,sportif, tabah, terbuka, dan tertib.Menurut Hasbi Assidiqqi (2015) dalam penelitiannya menyatakan bahwa pembelajaran matematika yang memuat komponen-komponen tersebut tidak hanya tujuan kognitif dicapai, tetapi tujuan untuk membentuk karakter peserta didik diharapkan dapat dicapai seperti: sikap ingin tahu, mandiri, kerja keras, logis, kritis, bertanggung jawab, percaya diri, toleransi, peduli, disiplin, demokratis dan komunikatif dan karakter positif lainnya. Ini maknanya, peserta didik yang lulus SMA perlu ditanamkan sikap Thustworthiness agar langkah pendidikan selanjutnya menjadi pribadi yang unggul dan berkarakter dalam mencapai cita-cita meski tempat pendidikan berbeda utuk menjaga nama baik pribadi, keluarga dan sekolah.
Berdasarkan penelitian yang telah dilakukan, peserta didik berlaku jujur dalam mengerjakan soal dengan tipe soal random dan pengawasan ketat. Peserta didik mengerti apa yang dikatakan dan apa yang harus dilakukan misalnya, besuk ada ujian peserta didik harus menyiapkan mental dan belajar teori yang diujikan. Peserta didik berani untuk melakukan hal yang benar misalnya, ada soal yang kurang jelas dan salah peserta didik berani untuk meminta penjelasan dari pengawas sehingga menjawab soal lebih terarah.

Hasil temuan penelitian pendidikan karakter Caring dengan perayaan kelulusan tidak konvoi dan coret-coret yang melanggar keamanan dan ketertiban orang lain dan melakukan pembagian takjil buka puasa untuk orang yang berada di perempatan lampu di jalan raya. Kelulusan merupakan tahapan akhir peserta didik menyelesaikan studi di tingkat SMA. Kegembiraan dan kebanggaan menghampiri peserta didik yang dinyatakan lulus. Perilaku corat-coret baju dan konvoi tidak jelas di jalan yang sebagian besar lulusan SMA melakukan justru tidak mencerminkan oran yang terdidik. Perayaan kelulusan peserta didik sebaiknya dilakukan dengan penuh kebaikan dan kedermawanan misalnya memberikan takjil buka puasa, mengumpulkan dana bantuan sosial untuk korban bencana alam dan fakir miskin, dan memberikan pakaian yang baik dan tidak terpakai kepada peserta didik yang sangat membutuhkan.Menurut Ari Ginanjar dalam Darmiyati Zuchdi,dkk. (2009) ada tujuh karakter dasarmanusia yang dapat diteladani dari nama-namaAllah, yaitu: (1) jujur, (2) tanggungjawab, (3)disiplin, (4) visioner, (5) adil. (6) peduli, dan(7) kerjasama.

Hasil temuan penelitian pendidikan karakter Respect dengan saling menghormati dan menghargai pencapaian hasil akademik antar peserta didik dan tidak melakukan halhal yang mengganggu orang lain seperti konvoi yang menimbulkan suara bising. Peserta didik tidak merayakan kelulusan dengan eforia dikarenakan pengumumannya melalui online sehingga meminimalkan kejadian yang tidak beradab dan kurang sopan 
antara peserta didik dan masyarakat. Peserta didik saling menghormati nilai yang diperoleh karena sudah usaha maksimal. Peserta didik tidak ada gesekan dan penghinaan antara yang bernilai tinggi dan bernilai rendah.

Hasil temuan penelitian pendidikan karakter Citizenship dengan perayaan lulusan dengan tidak melanggar aturan tata tertib sekolah dan tidak melanggar aturan hukum lalu lintas di jalan raya. Peserta didik menjadi warga sekolah yang baik karena segala ketentuan mulai dari masuk dan keluar tidak ada masalah kriminal, maknanya peserta didik mentaati tata tertib yang ada. Peserta didik bertanggung jawab dan berpartisipasi dalam pelayanan masyarakat misalnya, mengadakan bakti sosial dan pengaturan lalu lintas di depan sekolah. Peserta didik menghormati pendidik, kepala sekolah dan karyawan yang bekerrja di sekolah tersebut, saling tegur sapa intilah yang menjadi keakraban antar warga sekolah. Hal itu, akan diterapkan peserta didik saat sudah lulus studi di sekolah tersebut.

Hasil temuan penelitian pendidikan karakter Responsibility dengan menunggu pengumuman sesuai dengan aturan sekolah, apapun hasil akademik yang diperoleh tetap bersyukur dan melanjutkan ke langkah selanjutnya dengan memanfaatkan hasil akademik secara maksimal.Elkind (2004) bahwa pendidikan karakter ialah segala sesuatu yang dilakukan guru, yang dapat mempengaruhi karakter atau watak peserta didik. Seorang guru membantu membentuk watak peserta didik. Keteladanan bagaimana perilaku atau tingkah laku guru, cara guru berbicara atau menyampaikan materi serta bagaimana guru bertoleransi dengan peserta didik danberbagai hal yang terkait.Peserta didik akan bertanggung jawab dalam menjaga nama baik skolah di dunia kerja maupun di perkulihan setelah menyandang gelar alumni. Peserta didik akan melaksanakan ilmu yang diperoleh saat studi sekolah dengan berasaskan kebaikan, manfaat, sesuai dengan kaidah keilmuan dan ajaran agama serta tidak menyalah aturan yang menyimpang dari hukum. Peserta didik selain melanjutkan studi juga ada yang menerapkan ilmu kewirausahaan sehingga menabah pengetahuan dan pemahaan serta berani ambil resika dalam mendirikan usaha.

Membentuk produk hasil dari proses pendidikan (out come) agar memiliki karakter dan berkualitas hendaknya mempertimbangkan beberapa faktor, yaitu: (1) Merubah karakter pendidik yakni dapat dilihat dari apa yang dibicarakan dan bagaimana ia memaknai sesuatu yang bisa dilihat dari apa yang ia bicarakan. Pendidik yang tak bisa memahami anak didik itulah yang egois dan sering membuat anakanak didik teralienasi dalam dunia sekolah sehingga sekolah tak menyenangkan dan banyak yang justru ingin lari (2) Pendidik semestinya memiliki karakterprogresif yaitu jenis karakter kuat dan baikyang dibutuhkan bagi orang menyukaikemajuan. Karakter ingin maju berartiadalah karakter ingin mengubah keadaanyang dianggapnya kurang baik dan keadaanyang penuh masalah serta keadaan yangmenghambat kemajuan.(3) Setiap komponen yang ikut menentukan kualitas pendidikan di Indonesia harus samasama dibenahi, mulai dari visi-misi yang ingin dicapai, kurikulum pendidikan,sarana dan prasarana pendidikan, sampai kepada keadan peserta didik itu sendiri. (4) Meningkatkan mutu pelayanan dengan cara membandingkan harapan pelanggan atas layanan yang ideal dengan layanan yang mereka terima.

Pembelajaran abad 21menekankan pada kemampuan peserta didik dalam mencari tahu dari berbagai sumber, merumuskan permasalahan, berpikir analitis dan kerjasama serta berkolaborasi dalam menyelesaikan masalah (LitbangKemdikbud, 2013). Beberapa konsep pendidikan abad 21 yang telah diadaptasi oleh Kemendikbud Indonesia untuk dapat mengembangkan kurikulum dari tingkat Sekolah Dasar (SD), selanjutnya Sekolah Menengah Pertama (SMP), kemudian Sekolah Menengah Atas (SMA) konsep konsep tersebut antara lain: a) keterampilan abad 21 
(21st centuryskills). b) pendekatan ilmiah (scientific approach). c) pembelajaran otentik dan penilaian otentik (authenticlearning \& authentic assesment).

\section{Simpulan}

Dalam simpulan ini sebagaimana rumusan masalah ada 4 hal yang dapat disimpulkan.

1. Pendidikan karakter Thustworthiness dengan mengakui bahwa soal - soal yang diujikan dianggap sulit sehingga perlu belajar ekstra keras dan cerdas seperti mengerjakan soal HOTS, dan pengawasan ujian ketat sesuai dengan ketentuan yang ada.

2. Pendidikan karakter Caring dengan perayaan kelulusan tidak konvoi dan coret-coret yang melanggar keamanan dan ketertiban orang lain dan melakukan pembagian takjil buka puasa untuk orang yang berada di perempatan lampu di jalan raya.

3. Pendidikan karakter Respect dengan saling menghormati dan menghargai pencapaian hasil akademik antar peserta didik dan tidak melakukan hal-hal yang mengganggu orang lain seperti konvoi yang menimbulkan suara bising.

4. Pendidikan karakter Citizenship dengan perayaan lulusan dengan tidak melanggar aturan tata tertib sekolah dan tidak melanggar aturan hukum lalu lintas di jalan raya.

5. Pendidikan karakter Responsibility dengan menunggu pengumuman sesuai dengan aturan sekolah, apapun hasil akademik yang diperoleh tetap bersyukur dan melanjutkan ke langkah selanjutnya dengan memanfaatkan hasil akademik secara maksimal.

\section{Daftar Pustaka}

Abdul Azis, Hamka. 2012. Karakter Guru Profesional. Jakarta ; Al Mawardi

Prima.

Ahmadi.2007. Sosiologi Pendidikan.Jakarta : Rineka Cipta.

Bambang Sumardjoko.2015. Metodologi Penelitian Kualitatif.Surakarta : UMS.

Beland, K. and Team. National SchoolofCharacter: Award-Wi nningPractise,USA:

Character EducationPatnership, 2006.

Depdiknas. 2006. Panduan PengembanganSilabus. Jakarta: Depdiknas.

Dirjen Dikti. 2010. Kerangka AcuanPendidikan Karakter. Jakarta: 2010

Edward Sallis.2011.Total Quality Management in Education.Yogyakarta:

IRCisoD.

Elkind, David H. dan Sweet,Freddy. (2004). How to DoCharacter Education. Artikel yangditerbitkan pada bulanOktober 2004.

Kementerian Pendidikan Nasional. Panduan Pelaksanaan Pendidikan Karakter. Jakarta: BALITBANG Pusat Kurikulum dan Perbukuan, 2011.

Lickona, Thomas. Educating For Character: How Our School Can Teach Respect and Responsibility. New York: Bantam Books, 1992.

Samani, Muchlas, Hariyanto. Pendidikan Karakter. Bandung : PT Remaja Rosdakarya

Sofyan Anif.2014.Profesi Guru Antara Konsep, Implementasi, dan Pembinaan.Surakarta : BPFKIP UMS.

Syamsul Bahri.2010. Strategi Belajar Mengajar. Jakarta : Rineka Cipta. 
Taniredja,Tukiran.2016. Guru yang Profesional. Bandung : Alfabeta.

Tim Penyusun.2017. Pedoman Penulisan Tesis. Surakarta : SPs UMS.

Tim Penyusun. 2018.Teknik Penulisan Ilmiah Menggunakan Smart Word dan Management Reference.Surakarta : Laboratorium SPs UMS. 